\title{
The expression of the ACTH receptor
}

\section{L.L.K. Elias ${ }^{1,2}$ and} A.J.L. Clark ${ }^{1}$

\author{
${ }^{1}$ M olecular Endocrinology Laboratory, Department of Chemical Endocrinology, \\ St. Bartholomew's and the Royal London School of Medicine and Dentistry, \\ London, England \\ 2Divisão de Endocrinologia, D epartamento de Clínica M édica, \\ Faculdade de Medicina de Ribeirão Preto, U niversidade de São Paulo, \\ Ribeirão Preto, SP, Brasil
}

\section{Correspondence \\ L.L.K. Elias \\ Departamento de Clínica Médica \\ FMRP, USP \\ 14049-900 Ribeirão Preto, SP \\ Brasil \\ Fax: + 55-16-633-1144 \\ E-mail: Ilelias@ hotmail.com \\ Presented at the First \\ International M eeting on Adrenal \\ Disease: Basic and Clinical \\ Aspects, Ribeirão Preto, SP, Brazil, \\ August 31-September 2, 1999. \\ Publication supported by FAPESP. \\ $\ldots \ldots \ldots \ldots \ldots \ldots \ldots$}

Received February 25, 2000

Accepted March 22, 2000

\section{Abstract}

Adrenal glucocorticoid secretion is regulated by adrenocorticotropic hormone $(\mathrm{ACTH})$ acting through a specific cell membrane receptor (ACTH-R). The ACTH-R is a member of the G protein superfamilycoupled receptors and belongs to the subfamily of melanocortin receptors. The ACTH-R is mainly expressed in the adrenocortical cells showing a restricted tissue specificity, although ACTH is recognized by the other four melanocortin receptors. The cloning of the ACTH-R was followed by the study of this gene in human diseases such as familial glucocorticoid deficiency (FGD) and adrenocortical tumors. FGD is a rare autosomal recessive disease characterized by glucocorticoid deficiency, elevated plasma ACTH levels and preserved renin/ aldosterone secretion. This disorder has been ascribed to an impaired adrenal responsiveness to ACTH due to a defective ACTH-R, a defect in intracellular signal transduction or an abnormality in adrenal cortical development. Mutations of the ACTH-R have been described in patients with FGD in segregation with the disease. The functional characterization of these mutations has been prevented by difficulties in expressing human ACTH-R in cells that lack endogenous melanocortin receptor activity. To overcome these difficulties we used Y6 cells, a mutant variant of the Y1 cell line, which possesses a nonexpressed ACTH-R gene allowing the functional study without any background activity. Our results demonstrated that the several mutations of the ACTH-R found in FGD result in an impaired cAMP response or loss of sensitivity to ACTH stimulation. An ACTHbinding study showed an impairment of ligand binding with loss of the high affinity site in most of the mutations studied.

\section{Introduction}

Glucocorticoid secretion by the adrenal gland is under the control of pituitary adrenocorticotropin hormone (ACTH), which acts through a specific cell membrane receptor. The ACTH receptor (ACTH-R) is a member of the superfamily of $G$ protein (guanine

\author{
Key words \\ - ACTH receptor \\ - Resistance \\ - Mutation \\ - Transfection
}

nucleotide binding regulatory proteins)coupled receptors and belongs to the melanocortin receptor family (1). The first two receptors of this family cloned were the MSH$\mathrm{R}$, also named MC1-R, and the ACTH-R, also named MC2-R (2). Further investigations have identified three other receptors named MC3-R, MC4-R and MC5-R, which 
are involved in the melanocortin system in the brain and play a role in the control of weight homeostasis and in the autonomic control of the cardiovascular system $(3,4)$.

The ACTH-R is one the smallest G protein-coupled receptors identified, having a molecular weight of $33 \mathrm{kDa}$ and containing 297 amino acids. Two potential sites for Nlinked glycosylation in the extracellular Nterminal region may result in a molecule of $43 \mathrm{kDa}$. The ACTH-R is mainly expressed in the adrenal gland (2) and shows low expression in skin and adipose tissue $(5,6)$. The major specific expression of the ACTH-R in the adrenal is determined by the presence of specific regulatory elements in the promoter region of the ACTH-R gene. The orphan nuclear receptor steroidogenic factor 1 , a key regulator of adrenal development and function (7), has been shown to be involved in the regulation of the steroidogenic specific activity of the ACTH-R $(8,9)$. The induction of ACTH-R promoter activity is also sensitive to cAMP, which could explain the ACTH-R up-regulation through its own ligand $(10,11)$.

The ACTH-R shows an exclusive affinity for $\mathrm{ACTH}$, although this hormone is recognized by the other four melanocortin receptors $(12,13)$. The ACTH-R requires for ligand binding not only the conserved His-Phe-ArgTrp sequence but also a highly basic motif present solely in the ACTH molecule.

Following binding to the receptor, $\mathrm{ACTH}$ induces a conformational change that allows the $\mathrm{G}$ protein to interact with the receptor, eliciting the exchange of GDP for GTP and dissociation of the heterotrimeric $\mathrm{G}$ protein into an $\alpha$ subunit and a $\beta \gamma$ subunit. This activation ultimately results in an increase of cAMP, a second messenger that activates protein kinase A (PKA) which phosphorylates cAMP response element binding protein increasing the transcription of the genes involved in steroidogenesis such as steroidogenic regulatory protein (14). PKA also phosphorylates proteins on threonine and serine residues, a fact which is likely to be important for steroidogenesis (15). Cyclic AMP also acts by inhibiting a potassium channel resulting in an increase of intracellular calcium concentration (16).

\section{ACTH insensitivity}

Resistance to ACTH action has been described in a group of inherited disorders which includes familial glucocorticoid deficiency (FGD) and the triple A syndrome (adrenal failure, achalasia, alacrima) (17). Linkage analysis excluded the ACTH-R locus as the cause of triple A syndrome, leading to the search for another candidate gene which has mapped this disease to a locus on chromosome 12q13 $(18,19)$.

FGD is a rare autosomal recessive disease characterized by ACTH insensitivity with glucocorticoid deficiency, high plasma ACTH levels and normal renin-aldosterone axis. The pathogenesis of FGD has been ascribed to the following hypotheses: defect in adrenocortical development, degeneration of the adrenal gland, defect in the intracellular signalling response to $\mathrm{ACTH}$, and defect of the ACTH-R.

The cloning of the human ACTH-R gene in 1992 allowed the study of this gene in FGD and several mutations have been found in segregation with this disease (20-25). Mutations are distributed throughout the ACTH-R molecule and should result in different effects on receptor function.

In order to characterize the functional effects of the mutations found in FGD, expression studies were carried out using mutant ACTH-R. Previous studies used cells with some endogenous melanocortin receptor activity and their results did not permit a distinction between endogenous and transfected melanocortin receptor functions $(26,27)$. To overcome this difficulty we used Y6 cells which are a mutant variant of $\mathrm{Y} 1$ mouse adrenocortical tumor cells that possess a non-expressed ACTH-R gene and 
therefore show no background of melanocortin receptor activity. Using this cell line we could successfully express the human ACTH-R and characterized mutations found in FGD with an impaired cAMP response to ACTH or loss of sensitivity showing a right shift of the dose-response curve (28). Most of the mutations result in a loss of the high affinity ACTH binding site. As a group, we may consider the mutations as quantitative or qualitative defects according to the possibility of overcoming the defect with higher doses of ACTH. Moreover we found a variable degree of resistance to homologous desensitization by these ACTH-R mutations suggesting an impairment of $\mathrm{G}$ protein coupling (29). The resistance to ACTH-induced desensitization observed in ACTH-R mutations found in FGD could be a mechanism for preserving some cortisol production to overcome the receptor resistance to ACTH. Taken as a whole, the data obtained confirm the ACTH-R mutations as a cause of FGD.

\section{References}

1. Clark AJ L \& Cammas FM (1996). The ACTH receptor. Baillière's Clinical Endocrinology and Metabolism, 10: 29-47.

2. Mountjoy KG, Robbins LS, Mortrud MT \& Cone RD (1992). The cloning of a family of genes that encode melanocortin receptors. Science, 257: 1248-1251.

3. Mountjoy KG, Mortrud MT, Low MJ , Simerly RB \& Cone RD (1994). Localization of the melanocortin-4 receptor in neuroendocrine and autonomic control circuits in the brain. Molecular Endocrinology, 8: 1298-1308.

4. Adan RAH \& Gispen WH (1997). Brain melanocortin receptors: from cloning to function. Peptides, 18: 1279-1287.

5. Slominsk A, Ermak G \& Minm M (1996). ACTH receptor, CYP11A1, Cyp17 and CYP21A2 genes are expressed in skin. J ournal of Clinical Endocrinology and Metabolism, 81: 2746-2749.

6. Boston BA \& Cone RD (1996). Characterization of melanocortin receptor subtype expression in murine adipose tissues and in the 3T3-L1 cell line. Endocrinology, 137: 2043-2050.

7. Parker KL \& Schimmer BP (1997). Steroidogenic factor 1 : a key determinant of endocrine development and function. Endocrine Reviews, 18: 361-377.

8. Cammas FM, Pullinger GD, Barker $\mathrm{S} \&$ Clark AJ L (1997). The mouse adrenocorticotropin receptor gene: cloning of its receptor and evidence for a role for the orphan nuclear receptor steroidogenic factor 1. Molecular Endocrinology, 11: 867876.

9. Marchal R, Naville $D$, Durand $P$, Begeot $M$ $\&$ Penhoat A (1998). A steroidogenic factor-1 binding element is essential for ba- sal human ACTH receptor gene transcription. Biochemical and Biophysical Research Communications, 247: 28-32.

10. Penhoat A, J aillard C \& Saez J M (1989). Corticotropin positively regulates its own receptors and CAMP response in cultured bovine adrenal cells. Proceedings of the National Academy of Sciences, USA, 86: 4978-4981.

11. Naville D, Penhoat A, Durand P \& Begeot M (1999). Three steroidogenic factor-1 binding elements are required for constitutive and CAMP-regulated expression of the human adrenocorticotropin receptor gene. Biochemical and Biophysical Research Communications, 255: 28-33.

12. Cone RD, Lu D, Koppula S, Vage DI, Klungland $\mathrm{H}$, Boston B, Chen W, Orth DN, Pouton C \& Kestersonn RA (1996). The melanocortin receptors: agonists, antagonists, and the hormonal control of pigmentation. Recent Progress in Hormone Research, 51: 287-317.

13. Schioth HB, Chhajlani V, Muceniece R, Klusa V \& Wikberg J E (1996). Major pharmacological distinction of the ACTH receptor from other melanocortin receptors. Life Sciences, 59: 797-801.

14. Lehoux J G, Fleury A \& Ducharme L (1998). The acute and chronic effects of adrenocorticotropin on the levels of messenger ribonucleic acid and protein of steroidogenic enzymes in rat adrenal in vivo. Endocrinology, 139: 3913-3922.

15. Stocco DM \& Clark BJ (1996). Regulation of the acute production of steroids in steroidogenic cells. Endocrine Reviews, 17: 221-244.

16. Enyeart JJ \& Enyeart J A (1998). Activation of separate calcium and A-kinase-de- pendent pathways by ACTH. Endocrine Research, 24: 325-334.

17. Huebner A, Elias LLK \& Clark AJ L (1999). ACTH resistance syndromes. J ournal of Pediatric Endocrinology and Metabolism, 12: 277-293.

18. Weber $A$, Wienker TF, J ung $M$, Easton $D$, Dean HJ , Heinrichs C, Reis A \& Clark AJ L (1996). Linkage analysis of the gene for the triple A syndrome to chromosome 12 q13 near the type II keratin gene cluster. Human M olecular Genetics, 5: 20612066.

19. Stratakis CA, Lin J P, Pras E, Rennert OM Bourdony CJ \& Chan WY (1997). Segregation of Allgrove (triple A) syndrome in Puerto Rican kindreds with chromosome 12 (12q13) polymorphic markers. Proceedings of the Association of American Physicians, 109: 478-482.

20. Clark AJ L, McLoughlin L \& Grossman A (1993). Familial glucocorticoid deficiency caused by a point mutation in the ACTH receptor. Lancet, 341: 461-462.

21. Tsigos C, Arai K, Hung W \& Chrousos GP (1993). Hereditary isolated glucocorticoid deficiency is associated with abnormalities of the adrenocorticotropin receptor gene. J ournal of Clinical Investigation, 92: 2458-2461.

22. Weber A, Toppari J, Harvey RD, Klann RC, Shaw NJ , Ricker AT, Nanto-Salonen K, Bevan J S \& Clark AJ L (1995). Adrenocorticotropin receptor gene mutations in familial glucocorticoid deficiency: relationship with clinical features in four families. J ournal of Clinical Endocrinology and Metabolism, 80: 65-71.

23. Tsigos $C$, Arai $K$, Latronico AC, DiGeorge AM , Rapaport R \& Chrousos GP (1995). A 
novel mutation of the adrenocorticotropin receptor (ACTH-R) gene in a family with the syndrome of isolated glucocorticoid deficiency, but no ACTH-R abnormalities in two families with the triple $A$ syndrome. $\mathrm{J}$ ournal of Clinical Endocrinology and Metabolism, 80: 2186-2189.

24. Naville D, Barjhoux L, J aillard C, Faury D, Despert F, Esteva B, Durand P, Saez J M \& Begeot M (1996). Demonstration by transfection studies that mutations in the adrenocorticotropin receptor gene are one cause of the hereditary syndrome of glucocorticoid deficiency. J ournal of Clinical Endocrinology and Metabolism, 81: 1442-1448.

25. Wu SM, Stratakis CA, Chan CHY, Hallermeier KM, Bourdony CJ, Rennert
OM \& Chan WY (1998). Genetic heterogeneity of adrenocorticotropin (ACTH) resistance syndromes: identification of a novel mutation of the ACTH receptor gene in hereditary glucocorticoid deficiency. Molecular Genetics and Metabolism, 64: 256-265.

26. Weber A, Kapas S, Hinson J , Grant DB, Grossman A \& Clark AJ L (1993). Functional characterization of the cloned human ACTH receptor: impaired responsiveness of a mutant receptor in familial glucocorticoid deficiency. Biochemical and Biophysical Research Communications, 197: 172-178.

27. Naville $D$, Barjhoux L, J aillard C, Saez J M, Durand P \& Bégeot M (1997). Stable expression of normal and mutant human
ACTH receptor study of ACTH binding and coupling to adenylate cyclase. Molecular and Cellular Endocrinology, 129: 8390.

28. Elias LLK, Huebner A, Pullinger GD, Mirtella A \& Clark AJ L (1999). Functional characterization of naturally occurring mutations of the human adrenocorticotropin receptor: poor correlation of phenotype and genotype. J ournal of Clinical Endocrinology and Metabolism, 84: 2766-2770.

29. Elias LLK, Mirtella A \& Clark AJ L (1999). Impairment of desensitization by mutations of the human $\mathrm{ACTH}$ receptor $(\mathrm{ACTH}-$ R). 81st Annual Meeting of the Endocrine Society, J une 12-15, 1999, San Diego, CA, USA, P1-201 (Abstract). 